\title{
Når pasienten nekter å motta helsehjelp
}

\author{
Fra 1.1. 2009 inneholder pasientrettighetsloven et kapittel som gir \\ helsepersonell anledning til å bruke tvang for å sikre at personer uten \\ samtykkekompetanse får den helsehjelpen de trenger. Før det kan ytes \\ slik hjelp må tillitvekkende tiltak ha vært forsøkt. Det fremgår ikke hva \\ dette innebærer. Jeg mener at de nye reglene har begrenset anven- \\ delse, fordi man ofte kan komme til målet med god kommunikasjon.
}

\section{Halvor Nordby}

halvor.nordby@hil.no

Avdeling for helse- og sosialfag

Høgskolen i Lillehammer

2626 Lillehammer

og

Institutt for helseledelse og helseøkonomi Universitetet i Oslo

I § 4A-2 i det nye kapitlet heter det: «Kapitlet kommer til anvendelse når helsepersonell yter helsehjelp til pasienter over 16 år som mangler samtykkekompetanse [...] og som motsetter seg helsehjelpen» (1).

Intensjonen er forståelig. Noen av dem som motsetter seg behandling, er ikke i stand til å tenke noenlunde rasjonelt og foreta egne informerte og selvstendige valg. I disse tilfellene kan konsekvensene av ikke å behandle pasienten vurderes som så alvorlige og uforenlige med vedkommendes grunnleggende interesser at det er riktig å behandle mot vedkommendes vilje. Ved å klargjøre helsepersonells rett til å behandle pasienter uten samtykkekompetanse, er ideen at det skal bli enklere å vite når det er riktig bruke tvang.

Det nye kapitlet om bruk av tvang vil utvilsomt være til hjelp i en god del tilfeller. Pasientrettighetsloven har ikke inneholdt noen klare føringer for bruk av tvang når det ikke er mulig å innhente informert samtykke. I virkeligheten har vurderinger rundt bruk av tvang ofte vært regulert av helsepersonelloven $\S 7$ om at man skal yte nødvendig helsehjelp når det er påtrengende nødvendig (2). Samtidig er det grunn til å advare mot å utøve tvang for raskt. Det er uheldig hvis den nye loven bidrar til at terskelen for å behandle en person mot vedkommendes vilje oppfattes som svært lav, og at man bruker fysisk makt for tidlig, før man har forsøkt andre og mer humane virkemidler. I § 4A-3 står det at «før det kan ytes helsehjelp som pasienten motsetter seg, må tillitskapende tiltak ha vært forsøkt». Men det sies ikke noe mer konkret om hva dette innebærer.

\section{Kommunikasjon og realitetsorientering}

I mange tilfeller er det mulig å påvirke pasienters preferanser gjennom kommunikasjon selv om deres ønsker ikke er autonome - selv om de ikke er godt nok innforstått med situasjonen eller i stand til å tenke noenlunde rasjonelt $(3,4)$. Ideen om samtykkekompetanse er basert på begrepet autonomi: En person som ikke har evne til å foreta egne, autonome valg, har heller ikke kompetanse til å gi informert samtykke (3). Men det betyr ikke nødvendigvis at det er bortkastet tid å snakke med vedkommende. Klarer man å få pasienten til å skifte mening ved hjelp av en god samtale, er det bedre enn å behandle pasienten mot pasientens vilje.

Det første helsepersonell normalt bør forsøke å gjøre, er å gi pasienten balansert, objektiv kunnskap om vedkommendes helsesituasjon. Vi forsøker å realitetsorientere pasienten. Selvsagt kan dette noen ganger virke håpløst fra starten av. I ekstreme tilfeller kan forsøk på å realitetsorientere pasienten faktisk gjøre at pasienten i enda større grad motsetter seg behandling. Men i mange tilfeller er det mulig å få pasienten til å skifte mening (5). Poenget er at en person ikke alltid må være fullt ut autonom for å klare å forstå alvoret i situasjonen. En som virker omtåket fordi han har slått hodet på fest og gjerne vil fortsette festen ( «Jeg lover å kontakte lege i morgen»), kan forstå alvoret i situasjonen ved å bli ettertrykkelig informert om muligheten av alvorlig hodeskade. På samme måte kan en person i sterk rus forstå at det er fare for alvorlig helseskade hvis budskapet kommer klart og tydelig frem.

Ved å gi pasienter mer kunnskap om deres helsesituasjon kan det dermed være mulig å snu situasjonen. En kommunikativ strategi av denne typen er selvsagt fullstendig akseptabel etisk sett. Når man realitetsorienterer pasienter, gjør man det samme som vi i dagliglivet gjør når vi informerer andre mennesker om faktiske forhold.

Hvis det er viktig at en forvirret pasient raskt får behandling, så bør man selvsagt ikke bruke for mye tid på å overtale før man tar initiativ til behandling mot vedkommendes vilje. Situasjonen, og spesielt tidsaspektet og grad av fare for pasienten, vil være avgjørende. Ikke bare leger, også andre helsearbeidere (f.eks. ambulansepersonell) bør derfor ha kompetanse til å foreta rimelige vurderinger om dette. Samtidig er det viktig å huske at det kan være vanskelig å avgjøre om en person faktisk er autonom og har samtykkekompetanse. Da kan realitetsorientering i seg selv være en viktig nøkkel til å forstå om vedkommende er tilstrekkelig innforstått med sin egen helsetilstand og konsekvensene av sitt ønske.

Dette poenget blir ofte litt borte i diskusjoner om pasientautonomi. En klassisk fremgangsmåte for å vurdere om pasienter er autonome, er å tenke fremover i tid. Hvis det er god grunn til å tro at en person som ikke ønsker behandling vil forandre mening når han «kommer til seg selv» (pasienten kan være beruset, i sjokk eller ha en psykisk lidelse), så er det også god grunn til å tro at vedkommendes nåværende ønsker ikke er autonome (5). Problemet er at det kan være vanskelig å avgjøre om denne betingelsen er møtt. Kommunikasjon og realitetsorientering kan man imidlertid alltid anvende i situasjonen. Det er ikke nødvendig å gjøre antakelser om hva pasienten senere vil mene eller hva som egentlig er i vedkommendes beste interesse.

Kommunikasjon kan også være viktig etter at en beslutning om å behandle en pasient mot vedkommendes vilje er tatt. Når man venter på dem som skal utøve tvangen, bør man, hvis situasjonen ikke er vurdert som farlig eller kommunikasjonen bare skaper større psykologisk avstand, fortsette å fors $ø$ ke å realitetsorientere pasienten. Hvis pasienten i mellomtiden lar seg overtale, er jo verdifull tid spart.

\section{Når realitetsorientering ikke fører frem}

Hva skal man gjøre hvis man ikke klarer å overtale pasienten ved å formidle balansert og objektiv kunnskap om vedkommendes helsesituasjon? En annen strategi er mer ensidig vektlegging av informasjon og forklaringer som støtter ens egne vurderinger. Man kan f.eks. svært direkte og inngående formidle medisinsk kunnskap om 


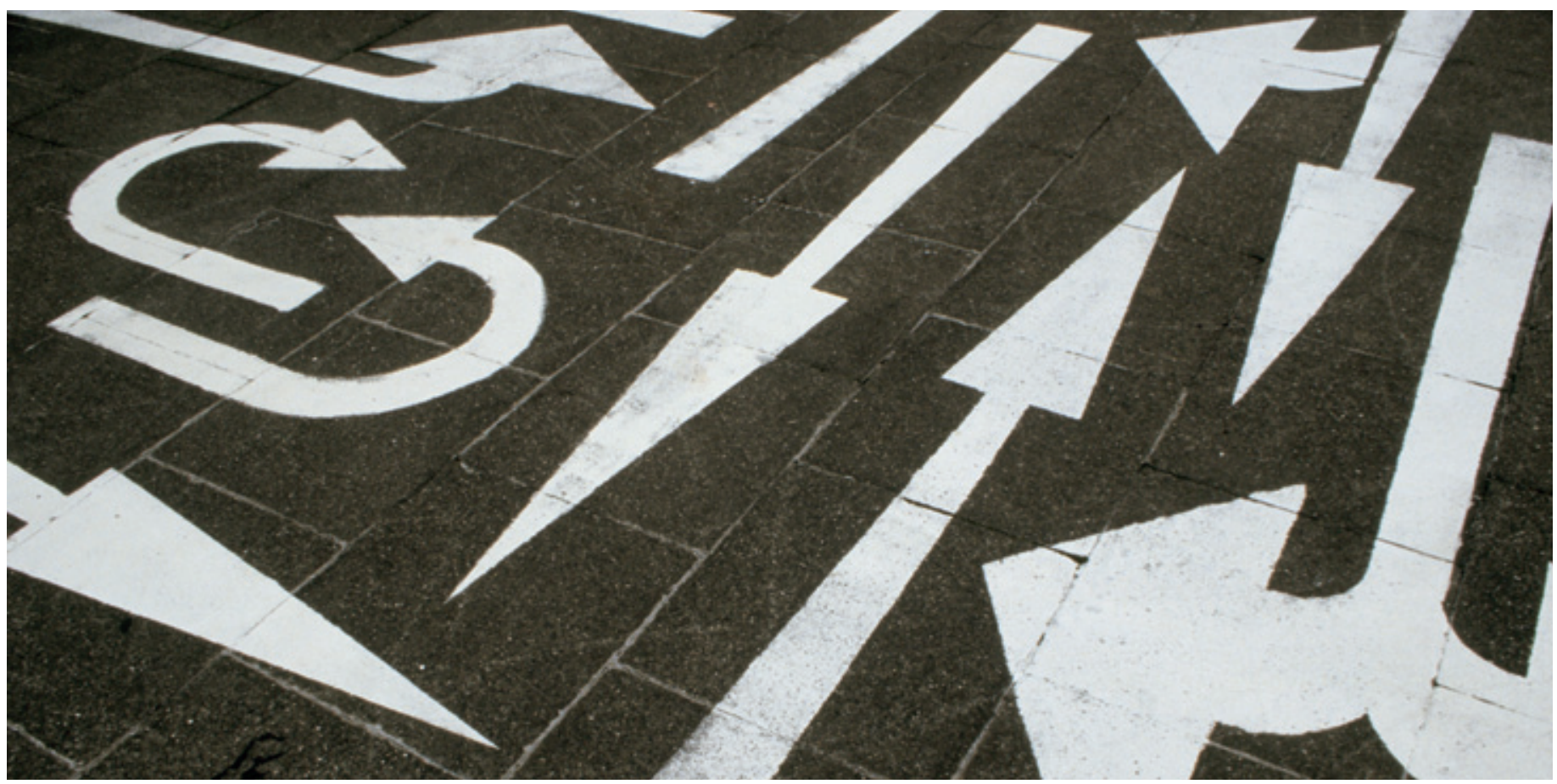

Gjennom god kommunikasjon kan legen hjelpe pasienten å finne riktig vei. Foto @ T. Callsen/plainpicture/Corbis/SCANPIX

mulige alvorlige årsaker til symptomene og samtidig være forsiktig med å snakke om at det «muligens ikke er noe alvorlig». En nøytral, balansert fremstilling vil ofte måtte inneholde informasjon som veier $i$ begge retninger. Mer ensidig vektlegging av negative konsekvenser av ikke å velge behandling kan være det som skal til for å få pasienten til å skifte mening.

Denne måten å snakke til pasienter på, er mer diskutabel - fordi man ikke lenger har et oppriktig ønske om å gi all objektiv informasjon. I virkeligheten bruker man virkemidler som er et hakk sterkere enn dem man anvender i kommunikasjon der målet er å formidle rasjonell innsikt i hele beslutningsgrunnlaget for en vurdering (6). Fremgangsmåten kan tilsynelatende også se ut til å være uforenlig med moderne idealer om informert samtykke, kunnskapsbasert kommunikasjon og symmetriske relasjoner mellom helsepersonell og pasienter $(7,8)$.

Jeg mener at det er uklart om disse idealene er tilpasset virkeligheten i mye medisinsk praksis. Satt på spissen: Hvis man kan få en pasient $i$ en alvorlig rustilstand til å forandre mening ved svært direkte og ensidig å legge vekt på negative konsekvenser for vedkommendes helse, er ikke det etisk sett bedre enn å utøve tvang? På samme måte kan man ofte svært tydelig og ettertrykkelig vektlegge konsekvenser av behandling som pasienten ikke har tenkt på og som vedkommende da ved nærmere ettertanke vurderer som mer positive enn han gjorde i første omgang.

Man må huske at dette bare kan brukes når det virkelig er god grunn til å tvile på om pasienten er autonom. Det negative som ligger i ikke å gi nøytral, balansert informa- sjon, må veies opp mot mulige konsekvenser av å la pasienten bestemme. I ekstreme tilfeller kan liv gå tapt hvis pasienten får bestemme, samtidig som det langt fra er klart om vedkommende har et reelt ønske om å dø. I disse situasjonene må det være et godt spørsmål hvor langt det er riktig å tøye grensene i forhold til grunnleggende normer om oppriktighet, sannhet og balansert informasjon i pasientkommunikasjonen.

Spørsmålet er egentlig helt generelt: I hvor stor grad er det riktig å bruke ubalanserte samtaleteknikker når det kan være snakk om å unngå svært alvorlige helsekonsekvenser for en pasient som ikke har samtykkekompetanse? Dette er et spørsmål som dessverre har fått for lite oppmerksomhet i medisinsk etikk. Diskusjoner om kommunikasjon og pasientsamtykke har i for stor grad vært tilpasset situasjoner hvor det er riktig å bruke mye tid og krefter på å forsøke å innhente informert samtykke innenfor trygge definerte rammer $(9,10)$. Disse rammene passer dårlig når tid, mangel på ressurser og den akutte alvorlighetsgraden av pasientens helsetilstand er kritiske faktorer. Slike begrensninger er en del av virkeligheten i en god del medisinsk praksis. Det er derfor behov for å utvikle begreper og metodeverktøy som bedre passer med denne virkeligheten.

\section{Oppsummering}

Jeg blir ofte ganske imponert når leger og annet helsepersonell i førstelinjetjenesten forteller hvordan de klarer å snu situasjoner ved hjelp av kreative samtaleteknikker. Poenget er at den nye loven om fullmakt til tvang lett kan bidra til at man ikke lenger tenker så mye på å få pasienten til å skifte mening etter en samtale. Det vil være uheldig. Å forandre preferanser ved hjelp av god kommunikasjon er alltid bedre enn å utøve tvang, også når pasientens ønsker ikke vurderes som autonome. Leger og annet helsepersonell bør derfor fortsatt ha et våkent øye for når dette er mulig.

\section{Oppgitte interessekonflikter: Ingen}

\section{Litteratur}

. Lov om endringar i pasientrettslova og biobanklova (helsehjelp og forsking - personar utan samtykkekompetanse). www.lovdata.no/cgi-wift/wiftIdles?doc=/usr/www/lovdata/all/nl-20061222 099.html\&emne=pasientrett*\&\& (29.12.2008)

2. Lov om helsepersonell m.v. (helsepersonelloven): § 7. www.lovdata.no/all/tl-19990702-064002.html\#7 (29.12.2008)

3. Young R. Informed consent and patient autonomy. I: Kuhse $H$, Singer $P$, red. A companion to bio ethics. Oxford: Blackwell, 2001: 441-52.

4. Beauchamp T. Philosophical ethics: an introduction to moral philosophy. New York: McGrawHill, 1991

5. Nordby H. Ethics for paramedics: consequences versus patients' autonomy. Akuttjournalen 2004; 11: $140-3$

6. Nordby H. Botten G. Kommunikasjon og helseledelse. Tidsskr Nor Lægeforen 2007; 127: 1080-2.

7. Ong L, de Haes J, Hoos A et al. Doctor-patient communication: a review of the literature. Soc Sci Med 1995; 40: 903-18.

8. Pendleton D, Tate P, Schofield T. The new consultation: developing doctor-patient communication Oxford: Oxford University Press, 2003.

9. Higgs R. On telling patients the truth. I: Kuhse H, Singer $P$, red. Bioethics: an anthology. 2. utg. Oxford: Blackwell, 2006: 611-9.

10. Gillon R. Telling the truth, confidentiality, consent and respect for autonomy. I: Harris J, red. Bioeth ics. Oxford: Oxford University Press, 2001: 507-29.

Manuskriptet ble mottatt 31.10. 2008 og godkjent 8.1. 2009. Medisinsk redaktør Erlend Hem. 